Ogawa, Y., J. Otsuka, S. Yamaguchi and O. Chigira (2008): The most favorable time for controlled pollination in Acacia auriculiformis. Annual Meeting of Japanese Forestry and Society 119: 139.

Pedley, L. (1978): A revision of Acacia Mill. in Queensland. Austrobaileya 1: 75-234.

Pinyopusarerk, K., E. R. Williams and D. J. Boland (1991): Variation in seedling morphology of Acacia auriculiformis. In: CARRON, L. T., AkEN, K. M., eds. Breeding technologies for tropical acacias. Canberra: Australian Centre for International Agricultural Research 36: 67-72.

RATHCKE, B. and E. P. LACEY (1985): Phenological patterns of terrestrial plants. Annual Review of Ecology and Systematics 16: 179-214.

Ryan, P. A., M. Podberscek, C. G. Raddatza and D.W. TAYLOR (1991): Acacia species trials in southeast Queensland, Australia. In: CARron, L. T., AKen, K. M., eds. Breeding technologies for tropical acacias. Canberra: Australian Centre for International Agricultural Research 36: 81-85.

SAKAI, S. (2001): Phenological diversity in tropical forests. Population Ecology 43: 77-86.

Sedgley, M., J. HaRbard, R. M. SMith and R. WiCKNESWARI (1991a): Development of hybridization techniques for Acacia mangium and Acacia auriculiformis. In: CARRon, L. T., AKEN, K. M., eds. Breeding technologies for tropical acacias. Canberra: Australian Centre for International Agricultural Research 37: 51-56.

Sedgley, M., W. C. Yong, V. Newman, J. Harbard, R. M. Smith, K. K. GHan and A. TAJUdDIN (1991b): Phenology of Acacia mangium and Acacia auriculiformis in Australia and Malaysia. In: CARRON, L. T., AKen, K. M., eds. Breeding technologies for tropical acacias. Canberra: Australian Centre for International Agricultural Research 37: 36-44.

Sedgley, M., J. HARBARD, R. M. SMith, R. WiCKNESWARI and A. R. GRIFFIN (1992): Reproductive biology and interspecific hybridization of Acacia mangium and Acacia auriculiformis A. Cunn.ex Benth. (Leguminoae: Mimosoideae). Australian Journal of Botany 40: 37-48.

SedGley, M. and J. HARBARD (1993): Pollen storage and breeding system in relation to controlled pollination of four species of Acacia (Leguminosae: Mimosoideae): Australian Journal of Botany 41: 601-609.

Siegel, S. and N. J. JR. CASTELlan (1988): Nonparametric Statistics for the Behavioral Sciences ( $2^{\text {nd }}$ ed.), McGrawHill.

THAM, C. K. (1976): Introduction to plantation species Acacia mangium Willd. Proceedings of the $6^{\text {th }}$ Malaysian Forestry Conference, Kuching, Sarawak, Malaysia: 153-158.

Visser, T., D. P. D. E. VRIES, G. W. H. Welles and J. A. M. ScheURINK (1977): Hybrid tea-rose pollen. I. Germination and storage. Euphytica 26: 721-728.

WICKNESWARI, R. and M. NORWATI (1993): Genetic diversity of natural-populations of Acacia auriculiformis. Australian Journal of Botany 41: 65-77.

YAMAGUCHI, S. and Y. OGAWA (2008): Discussion of germination test and storage method in relation to pollens of Acacia auriculiformis. Special Issue of Tree Breeding: 16-19.

\title{
Statistical associations between morphology, physiology and AFLP DNA markers enable selection of a putative eucalypt hybrid able to tolerate salt affected floodplains
}

\author{
By G. R. Koerber ${ }^{\left.1),{ }^{*}\right)}$ and T. HANCOCK ${ }^{2)}$
}

(Received $2^{\text {nd }}$ February 2012)

\begin{abstract}
A naturally occurring putative hybrid between Eucalyptus largiflorens F. Muell and Eucalyptus gracilis F. Muell called Green Box tolerates saline conditions of the River Murray floodplains better than E. largiflorens. Revegetation strategies utilizing seedlings of Green Box

\footnotetext{
1) School of Biological Sciences, Flinders University of South Australia, G.P.O. Box 2100, Adelaide, South Australia 5001, Australia. Precinct, Urrbrae, South Australia 5064, Australia.

*) Corresponding author: Georgia R. KoERBER. E-Mail: g.koerber@internode.on.net
}

2) BiometricsSA (Adelaide University/SARDI), Waite Research
\end{abstract}

have had limited success because only a few are Green Box and the majority are throw backs to $E$. gracilis and $E$. largiflorens. Therefore, the purpose of this study was to identify traits characteristic of Green Box and AFLP markers associated with the traits enabling selection at the seedling stage. This was done by non-linear canonical correlation analysis (OVERALS) to test for statistically significant associations between morphological and physiological traits with 232 AFLP markers from 9 primer combinations. OVERALS with all markers produced $1^{\text {st }}$ and $2^{\text {nd }}$ dimensions accounting for 80 and $74 \%$ of variation respectively. Green Box plants were placed intermediate between $E$. gracillis and $E$. largiflorens according to leaf colour, gloss and nitrogen with compo- 
nent loadings $\left(l_{c}\right)$ of $0.340,0.615$ and 0.294 respectively. A second approach of simple linear regression of morphological and physiological traits against all 232 AFLP markers singled out 17 with significance $P<0.05$. Thirteen of these were also identified by OVERALS. Four occurred with high frequency in Green Box and E. largiflorens distinguishing them from $E$. gracilis. In order to separate Green Box and E. largiflorens, the segregation of a further three markers can be used to align Green Box with $E$. gracilis. Therefore, the segregation of 7 markers can be utilized to select Green Box.

Key words: Eucalyptus, Australia, salt, re-vegetation, hybrid selection, AFLP marker.

\section{Introduction}

Prior to Murray River regulation, inundation of the Chowilla floodplain in South Australia (136 000 ML day1) occurred every 13 years whereas now for the same return period, flows of $76000 \mathrm{ML}^{-1 a y^{-1}}$ flood less than half of the floodplain (OverTon and Doody, 2010; SHARLEY and HugGAN, 1995). The lack of floods has caused drought, and salt inherent in these ancient river soils is no longer regularly transported away from the floodplain. Instead salt has built up to detrimental concentrations. Rainfall is less than $350 \mathrm{~mm}$ annually therefore plants rely on flooding for replenishment and leaching of salt from the root zone (KINGSFORD, 2000). Along the length of the Murray River in Australia, it is estimated that approximately 18000 ha of floodplain vegetation is severely degraded with saline ground water (MARGUles AND PARTNERs et al., 1990). High incidence of dieback amongst $E$. largiflorens and $E$. camaldulensis woodlands was a striking aspect of a biological survey conducted by O'MALLEY and SHELDON (1990).

Amongst deteriorating stands of $E$. largiflorens, Green Box plants were identified because of their healthy appearance. Green Box is characterised by bright, dense, glossy green foliage distinctly different to large glaucous grey-green leaves of $E$. largiflorens (PARSONS and ZubriniCH, 2010; Zubrinich et al., 2000). Although Green Box are less common, several hundred have been catalogued extending the length of the Murray Darling Basin (J. Seekamp unpublished). Green Box are hypothesized to be hybrids between $E$. largiflorens and Eucalyptus gracilis F. Muell, a mallee eucalypt inhabiting sandy escarpments up off the floodplain. Characteristics of $E$. gracilis include multiple stems, lignotubers, rough bark at the base and smooth whitish bark throughout the remainder, glossy green leaves (JESSOP et al., 1986) and flowers with staminodes (BROOKER, 2000).

With respect to physiological traits, Green Box had more negative water potentials, pre-dawn and midday, compared to $E$. largiflorens growing at the same sites, indicating they were able to uptake water from drier or more saline soil (ZUBRINICH et al., 2000). Green Box also has smaller xylem vessels. It is likely that Green Box inherited both of these traits from $E$. gracilis which have more negative water potentials and small xylem vessels. Mallees have lignotubers which were shown by MYERS (1995) to resist water flow and accounted in part for persistently more negative predawn water potentials in Eucalyptus behriana F. Muell.
There is an inherent salt tolerance of $E$. largiflorens specimens sampled from Clear Lake, western Victoria. These plants tolerated $380 \mathrm{mM} \mathrm{NaCl}$, when salt tolerance was defined as withstanding $300 \mathrm{mM} \mathrm{NaCl}$ (BLAKE, 1981). Green Box had significantly higher leaf $\mathrm{Na}^{+}$and $\mathrm{Cl}^{-}$compared to $E$. largiflorens $(P<0.01)$ (ZUBRINICH et al., 2000). There was less $\mathrm{Na}^{+}$compared to $\mathrm{Cl}^{-}$and this has been similarly observed in Eucalyptus microtheca F.J. Muell, from Marree, South Australia, the lowest rainfall in Australia and Eucalyptus microcorys F. Muell, particularly at the highest salt level of $150 \mathrm{mM}$ (CHEN et al., 1998; MoRABito et al., 1994).

Saline affected areas of the Chowilla floodplain have been re-vegetated with seedlings and clones of mature Green Box. Adult Green Box are readily distinct but seedlings are not and because the majority were throwbacks to either $E$. largiflorens or $E$. gracilis they suffered from the salinity of the floodplain. Clones tolerated the saline floodplain however a drawback is limited genetic diversity. Therefore a combined approach of traits associated with molecular markers will help to identify Green Box seedlings.

To screen for Green Box, characteristic morphological and physiological traits will be measured among natural stands of E. largiflorens, E. gracilis and Green Box. To enhance identification of suitable traits, links will be explored with amplified fragment length polymorphisms (AFLP) DNA markers (Vos et al., 1995). AFLP DNA markers have been utilised extensively for screening purposes (MCKINNON et al., 2008; WANG et al., 2005). DNA markers or morphological traits segregating with physiological traits may be easier and quicker to score as physiological traits are time consuming to measure routinely in a screening process. For example, a correlation between leaf size and absisic acid (ABA) in rice enabled selection for drought resistance such that plants with smaller leaf sizes were more likely to have higher levels of ABA (QUARRIE et al., 1997).

In this study, traits characteristic of Green Box identified by ZUBRINICH et al. (2000) will be utilised. Morphological traits include leaf colour, gloss and bark. In addition, new traits will be explored that indicate resource partitioning away from plant growth when plants are experiencing salinity stress. These traits determine the growth potential of a species (LAMBERS et al., 2008; Poorter and Evans, 1998) and include specific leaf area (SLA), leaf total nitrogen and carbon, and natural abundance of carbon and nitrogen isotopes (KOERBER et al., 2012). Lower SLA is hypothesised to be a result of evolutionary selection pressure for leaves with long life spans, thus retaining nutrients longer in nutrient poor environments (SCHIEVING and POORTER, 1999; WRIGHT et al., 2004). Other hypothesised strategies involving reduced SLA are accumulation of secondary compounds to detract herbivores and accumulation of lignin to facilitate survival during dry or cold environmental conditions (PoORTER and GARNIER, 1999). Measurement of biomass composition of carbon and nitrogen gives an indication of resource partitioning, either into photosynthetic apparatus or structural components (LAMBERs et al., 2008; LlOYD et al., 1992; NinemETs, 1999; REICH et al., 
1998). In a comparison of evergreen and deciduous species, evergreen species were hypothesised to possess a higher cost-benefit ratio attributed to longer-lived leaves, lower SLA, lower nitrogen content, and lower assimilation on a mass basis (EAMUs et al., 1999). Although investment in growth of leaves construction of leaves/growth is more expensive, maintenance costs are lower and affordable over a longer payback interval (longer-lived leaves) (EAMUs et al., 1999).

Nitrogen isotope $\left(\delta^{15} \mathrm{~N}\right)$ abundance in plant tissue is hypothesised to be affected by changes in assimilation activity when salinity was imposed on barley plants (HANDLEY et al., 1997; RoBINSON et al., 2000). Furthermore, HANDLEY et al. (1997) speculated $\delta^{15} \mathrm{~N}$ patterns might be produced under natural conditions for plants with slower growth habits and that the patterns would overlay variations in source (soil) $\delta^{15} \mathrm{~N}$.

The objective of this study is to screen for Green Box seedlings using characteristic morphological and physiological traits and AFLP DNA markers.

\section{Methods and Materials}

\section{Location}

The Chowilla floodplain is centred on the South Australia-Victoria-New South Wales Borders (14052'E $33^{\circ} 59$ 'S) covering approximately $200 \mathrm{~km}^{2}$ (JARWAL et al., 1996). It is the largest floodplain forest on the lower Murray River (KINGSFORD, 2000) and is part of 'Riverland Wetlands' listed under the UNESCO Ramsar Convention (Section 14.5) as wetlands of international importance because of unique bird-life and woodlands of $E$. camaldulensis and E. largiflorens (NEC, 1988). The area is located away from the moderating influence of the ocean and experiences generally clear skies allowing free heat exchange. Yearly rainfall is low, averaging $250-300 \mathrm{~mm}$, and potential evaporation is about 2000 mm (JARWAL et al., 1996).

\section{Sites and Trees}

The Chowilla floodplain is located within the Riverland Biosphere Reserve (RBR). Throughout RBR, 66

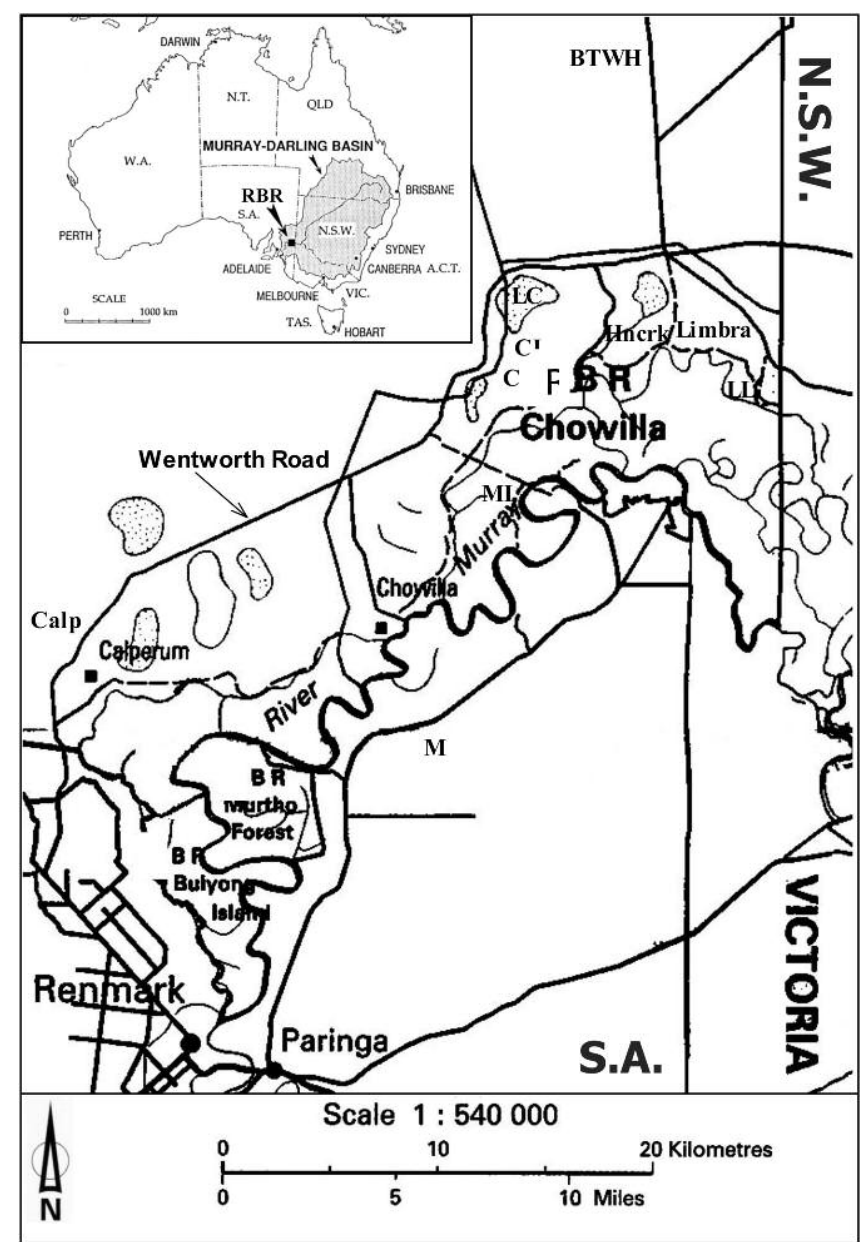

Figure 1. - Local-area sites within the Riverland Biosphere Reserve (RBR). Inset shows location of RBR. The table below shows abbreviations for sites and their GPS coordinates.

\begin{tabular}{|c|c|c|c|c|c|}
\hline Site & Label & GPS & Site & Label & GPS \\
\hline Coombool & $\mathrm{C}$ & $\mathrm{S} 33^{0} 55^{\prime}$ E $140^{0} 54^{\prime}$ & Hancock Creek & Hncrk & $\mathrm{S} 33^{0} 55^{\prime}$ E $140^{\circ} 55^{\prime}$ \\
\hline Coombool Inlet & $\mathrm{CI}$ & $\mathrm{S} 33^{0} 55^{\prime}$ E $140^{0} 54^{\prime}$ & Box Tree Waterhole & BTWH & $\mathrm{S} 33^{\circ} 50^{\prime}$ E $140^{\circ} 56^{\prime}$ \\
\hline Monoman Island & MI & $\mathrm{S} 33^{\circ} 57^{\prime}$ E $140^{\circ} 52^{\prime}$ & Calperum & Calp & $\mathrm{S} 34^{\circ} 02^{\prime} \mathrm{E} 140^{\circ} 40^{\prime}$ \\
\hline Lake Coombool & $\mathrm{LC}$ & $\mathrm{S} 33^{0} 55^{\prime}$ E $140^{0} 54^{\prime}$ & Limbra & Limbra & $\mathrm{S} 33^{0} 53^{\prime}$ E $140^{\circ} 58^{\prime}$ \\
\hline Lake Littra & LL & $\mathrm{S} 33^{0} 55^{\prime}$ E $140^{0} 59^{\prime}$ & Murtho & $\mathrm{M}$ & $\mathrm{S} 34^{\circ} 03^{\prime}$ E $140^{\circ} 51^{\prime}$ \\
\hline
\end{tabular}


adult trees were sampled from 'local-area' sites (23 E. largiflorens, 16 Green Box, 18 progeny of Green Box and 9 E. gracilis). The sites Coombool (C), Coombool Inlet (CI), Monoman Island (MI), Lake Coombool (LC) and Lake Littra (LL) were chosen because Green Box naturally occurs there. At Hancock Creek (Hncrk), there were approximately 50 seedlings each of Green Box (Hancock creek progeny) and E. largiflorens planted in 1991. The E. largiflorens seedlings were purchased from Wand F Nursery at Berri (J.V. Seekamp, pers. comm.) and their seed source is unknown. The sources of the Green Box seedlings were mature Green Box plants located on the floodplain. They were also the source of approximately 700 clonal Green Box plantlets planted in 1994. The clones were produced by tissue culture carried out by Dr T.C. Lee, Adelaide Botanic Gardens (J.V. Seekamp, pers. comm.). From each of these three types of revegetation plantings, five plants growing under similar soil and environmental conditions were chosen. In addition, two nearby mature $E$. largiflorens plants and one mature Green Box plant were chosen. Box Tree Waterhole (BTWH) was chosen because it is an isolated population of Green Box and E. largiflorens surrounded by $E$. gracilis mallee scrub. All three taxa were available for comparison within approximately $100 \mathrm{~m}^{2}$ and were thus growing under similar soil and environmental conditions. There were four Green Box plants and the four closest $E$. largiflorens and $E$. gracilis plants were chosen for comparison. Calperum (Calp) and Limbra were chosen because they were stands of $E$. gracilis located close to the floodplain. A further site, Murtho (M), was chosen because there was a mature $E$. largiflorens and a mature $E$. gracilis with several younger trees, greater than 10 years old (Murtho progeny), occurring on the edge of a field and isolated from other trees. The locations of local-area sites are shown in Fig. 1.
In addition, 10 trees of $E$. largiflorens and $E$. gracilis were sampled from allopatric populations using the Australian National Herbarium web site (http://www.anbg. gov.au/cpbr/anhsir/anhsir-manual/index.html, accessed $3^{\text {rd }}$ October 2012). E. largiflorens were sampled from Wilcannia approximately $450 \mathrm{~km} \mathrm{NE}$ of the local-area, and $E$. gracilis were sampled from Port Lincoln, approximately $450 \mathrm{~km} \mathrm{SW}$ of the local-area.

\section{Morphological Traits}

From each tree, colour and gloss of 25 leaves was recorded from small branches while fresh. Leaf colour was recorded using a Royal Horticultural Society (R.H.S. London) colour chart produced in conjunction with the Flower Council of Holland (Leiden). Each tree was assigned to one of six colour categories ranging from Yellow Green through Green to Grey Green. Leaf gloss was recorded as Dull, Intermediate or Shiny. Rough bark extends to the stem tips in $E$. largiflorens whereas in $E$. gracilis it terminates above the butt and is intermediate in Green Box. Therefore, the diameters of the main trunks/stems at the point where rough bark $\left(R b_{\mathrm{d}}\right)$ terminated were measured for all plants as a distinguishing trait.

\section{Physiological Traits}

From each tree four healthy mature leaves located at the fourth node below the stem tip were sampled and kept fresh for measurement of leaf area with a portable area meter (Model LI-3000 Li-Cor, U.S.A). Specific leaf area (SLA) was calculated from the ratio of leaf area to dry leaf weight $\left(\mathrm{cm}^{2} \mathrm{~g}^{-1}\right)$. Leaves were then dried and ground to fine powder consistency for determination of carbon and nitrogen isotope discrimination by mass spectrometry (Model GEO 20 -20 Dual Inlet, Europa Scientific Ltd., England). Sample weights required for

Table 1. - Nucleotide sequences for adaptors, preamplification primers and selective primers. The reverse of the core primer sequences minus the last nucleotide, corresponds to the reverse adaptor sequences $\left(5^{\prime} \rightarrow 3\right.$ '). Sequences for EcoRI are according to (Vos et al., 1995) except for A in brackets was a C in the current study.

\begin{tabular}{|c|c|}
\hline I abel & Sequence $\left(5^{\prime} \rightarrow 3^{\prime}\right)$ \\
\hline & Adaptor sequences \\
\hline $\operatorname{EoR} \mathrm{R}$ & CICGIAGAC IGCGIACC \\
\hline & ААT TGGTACGCAGTA TAC \\
\hline Msel & GACGATGAGTCC TGAG \\
\hline & IACICAGGACICAI \\
\hline$P s l$ & CTCGTA GAC TGCGTA CAT GC $\Lambda$ \\
\hline & $1 G 1 \mathrm{ACGCAG} \mathrm{ICT} \mathrm{AC}$ \\
\hline & Core primer sequenees \\
\hline FGORl & GACTGCGTACCA $\triangle T T C$ \\
\hline Msel & GATGAGTCC TGAGTA $A$ \\
\hline$P s / I$ & $\operatorname{GAC} \operatorname{IGCGTACAIGCAG}$ \\
\hline $\mathrm{PCR}$ & primer sequences (core primer $\cdot$ nucleolide(s)) \\
\hline Pre amplification $\mathrm{PCR}$ & Solective PCR \\
\hline FGoR I core primer $+\Lambda$ & EcoRI core primer $-\Lambda C T$ \\
\hline & EroRI core primer $-\triangle \mathrm{TG}$ \\
\hline Msel core primer $+\mathrm{C}$ & Msel core primer $+\mathrm{CCC}$ \\
\hline & Mel coreprimer $+\mathrm{CAG}$ \\
\hline & Msel corc primor + CCA \\
\hline Pstl core primer - A & Pstl core primer $+\mathrm{AG}$ \\
\hline
\end{tabular}


accurate measurements, determined from preliminary runs, were $1.5 \mathrm{mg}$ and $4 \mathrm{mg}$ for carbon and nitrogen respectively. Carbon isotope deviations $\left(\delta^{13} \mathrm{C}\right)$ were measured against 'Vienna'-Pee Dee Belemnite (PDB) (DAWSON and BROOKS, 2001). Nitrogen isotope deviations $\left(\delta^{15} \mathrm{~N}\right)$ were measured against the standards N1, N2 and N3. These standards are relative to atmospheric $\mathrm{N}_{2}$ according to the International Atomic Energy Agencies (IAEA) standards (DAWSON and BROOKS, 2001). Precision for nitrogen and carbon was quoted as $\leq \pm 0.2 \%$ and $\leq \pm 0.1 \%$ respectively (Europa Scientific Ltd.). Carbon deviation ( $\delta$ ) was converted to standard discrimination $(\Delta)$ values using the equation:

$$
\begin{gathered}
\delta=\left(\left(\delta_{a} / 1000\right)-\left(\delta_{p} / 1000\right)\right) /\left(1+\left(\delta_{p} / 1000\right)\right) \\
\text { Units: } \% \text { oor mil })
\end{gathered}
$$

Where $\delta_{a}$ is free atmospheric $\mathrm{CO}_{2}$ on the PDB scale and has an approximate value of $-8 \%$.

$\delta_{p}$ is $\mathrm{CO}_{2}$ of plant material, typical $\mathrm{C}_{3}$ plant on the PDB scale has a value of $-27.6 \%$ (FARQUHAR et al., 1989). Nitrogen is commonly expressed as deviation units in per mil (\%o) (HöGBERG, 1997). Carbon and nitrogen discrimination was measured from adult $\left(\Delta^{13} \mathrm{C}_{\mathrm{ad}}\right.$ and $\left.\delta^{15} \mathrm{~N}_{\mathrm{ad}}\right)$ and juvenile $\left(\Delta^{13} \mathrm{C}_{\mathrm{j}}\right.$ and $\left.\delta^{15} \mathrm{~N}_{\mathrm{j}}\right)$ leaves. Mass spectrometry also provides total carbon and nitrogen of adult $\left(T C_{\mathrm{ad}}\right.$ and $\left.T N_{\mathrm{ad}}\right)$ and juvenile leaves $\left(T C_{\mathrm{j}}\right.$ and $\left.T N_{\mathrm{j}}\right)$.

\section{Extraction of DNA}

Mature leaves at the fourth node with minimal blemishes or signs of insect attack were chosen to avoid red pigments (anthocyanins) and tannins present in younger leaves (SKABO et al., 1998); (Dr. R.E Vaillancourt and Dr. B. M. Potts, University of Tasmania, Australia, Pers. Com.). Leaves were picked into $50 \mathrm{~mL}$ centrifuge tubes (Sarstedt Australia Pty. Ltd.) and placed into liquid nitrogen then stored at $-80^{\circ} \mathrm{C}$ upon return from the field. DNA was extracted according to standard procedures (BYRNE et al., 1996; BYRNE et al., 1993). Some modification to the procedures are derived from DOYLE (1991) and Doyle and Doyle (1990) to account for high concentrations of hydrophobic compounds in Eucalyptus leaves.

\section{AFLP Analysis}

AFLP was carried out using protocols derived from Vos et al. (1995) and PARKER (1998). The only modification was addition of $2 \mu \mathrm{L}$ RL DNA instead of $4 \mu \mathrm{L}$ to improve clarity of marker banding profiles. A total of 9 primer combinations were screened and markers ranged from 50 to $600 \mathrm{bp}$ (Table 1). EcoRI/MseI primer sequences were chosen according to published studies involving Eucalyptus species (GAIOTTO et al., 1997; MARQUES et al., 1998). Pst I/MseI primer sequences were chosen based on recommendations by G. Parker and the fact that Pst I is highly methylation sensitive to target coding regions (PowEll et al., 1997; Young et al., 1999). EcoRI or PstI selective primers were radioactively labelled with ${ }^{33} \mathrm{P} \gamma \mathrm{ATP}$. PCR products were visualised on $6 \%$ polyacrylamide gels (19:1) [40mL SequaGel-6, $10 \mathrm{~mL}$ SequaGel Complete Buffer and $500 \mu \mathrm{L} 10 \%$ APS] cast between $35 \times 43 \mathrm{~cm}$ glass plates for running in a Heofer $^{\circledR}$ SQ3 Sequencer apparatus. Marker ladder was radioactively labelled pUC19 $M s p I$. Vacuum dried gels were exposed onto Kodak Diagnostic Film $(35 \times 43 \mathrm{~cm})$ X-Omat $^{\mathrm{TM}} \mathrm{K}$ XK-1 for 3 days then developed in a KODAK X-OMAT 1000 Processor, KODAK (Australasia) Pty. Ltd. AFLP marker presence or absence data was collected by blind sampling conducted by two volunteers with no knowledge of sample identities.

\section{Data Analysis}

All data analysis was carried out in SPSS (IBM SPSS Statistics 19 USA). All data was checked for normality and homogeneity of variance by carrying out Levene's test and transformations were applied if necessary. To examine associations between physiological and morphological traits with AFLP markers, two statistical approaches were undertaken: non-linear Canonical Correlation Analysis (OVERALS) and linear regression with randomization (HANCOCK, 2002).

OVERALS is similar to Principal Component Analysis (PCA), however two or more sets of variables with cases (trees) in common are correlated (CONNOLLY, 1997). OVERALS is suitable for scale traits such as physiological traits and discrete traits such as genotypes of molecular markers. In this study, the two sets are traits (morphological and physiological) and AFLP markers. OVERALS produces "dimensions" maximally correlating the sets. Eigenvalues from OVERALS can be interpreted as $r^{2}$ (fit) and their square root, canonical correlations, can be interpreted as Pearson's $r$, with values greater than 0.30 explaining acceptable variance (GARSON, 2002). Output includes "component loadings" $\left(l_{c}\right)$ for interpreting correlations between variables and each dimension. Plotting $1^{\text {st }}$ and $2^{\text {nd }}$ dimensions, using object scores (trees, cases) and component loadings (variables) produces a diagrammatic representation of the relationship between traits and AFLP markers. Variables positioned further from the origin contribute more to variation between trees. Type II error or underestimation was minimized by including at least 20 times as many cases as variables for interpreting the 1st dimension reliably (STEVENS, 1986).

Two OVERALS analyses were conducted with the same morphological and physiological traits. Firstly, OVERALS including all 232 AFLP markers proceeded by nominating 10 sets of variables to ensure number of cases (trees) exceeded number of variables. The first set comprised morphological and physiological traits and the remaining 9 were AFLP markers split by primer combination. Accompanying MANOVAs (Multivariate Analysis of Variance) were conducted and Wilks's lambda tested whether the variable sets were significantly correlated (GARSON, 2002). Categorical traits were treated as unordered variables (multiple nominal in SPSS). The second OVERALS was of trees from the local-area with 11 AFLP markers identified within the local-area that were at least $78 \%$ specific for either $E$. largiflorens (5 markers) or E. gracilis (6 markers).

The second statistical approach of linear regression would be straightforward if only one marker was used with either its presence or absence scored. The observed variance ratio would be tested with a critical value associated with a significance level of $5 \%(0.05)$. The difficul- 

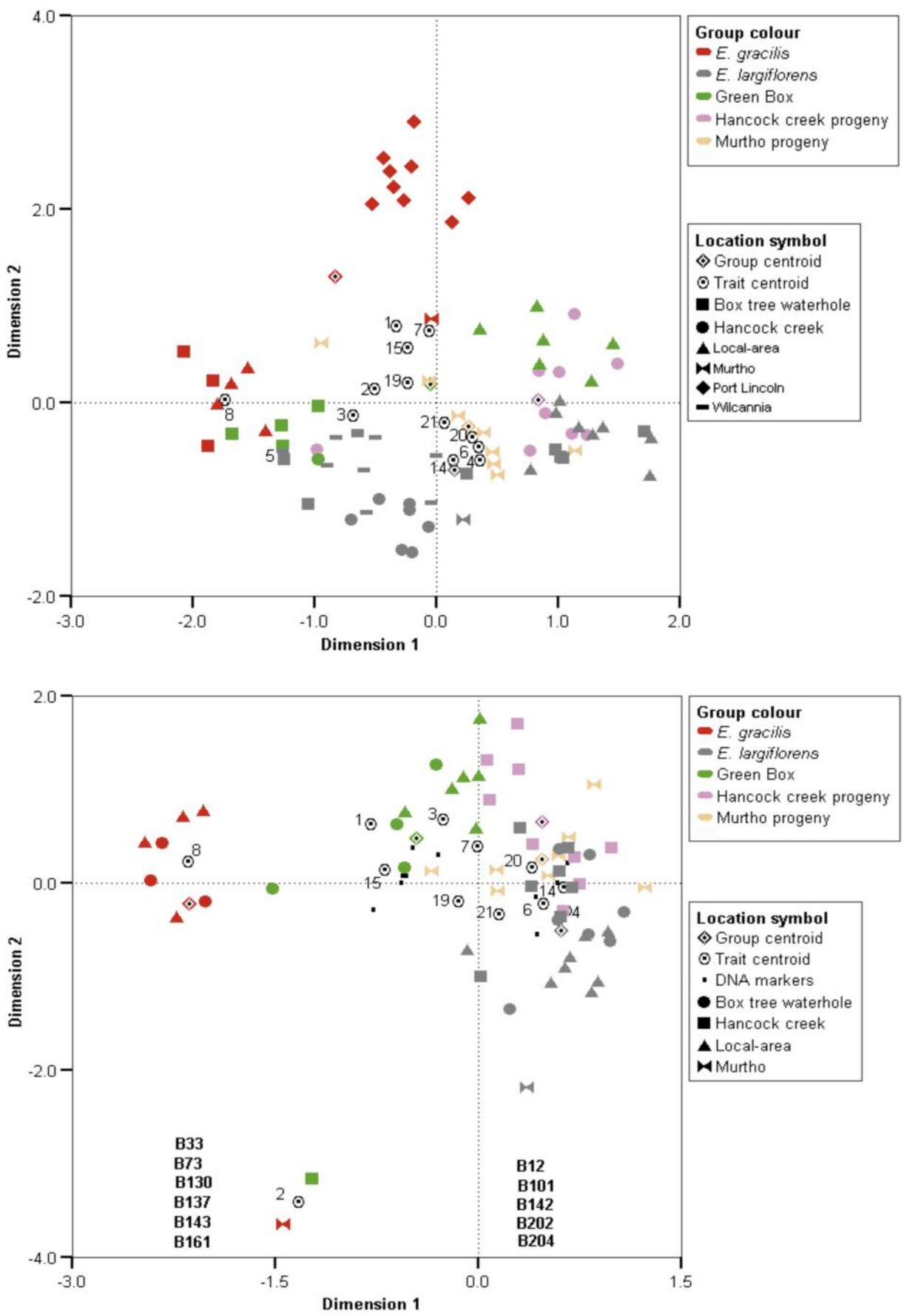

Figure 2. - OVERALS analyses of: a, All 232 AFLP DNA markers and b, eleven at least $78 \%$ specific markers within the local-area associated with morphological and physiological traits. First and $2^{\text {nd }}$ dimensions in a, account for $80 \%$ and $74 \%$ of the total variance respectively, in b, account for $95 \%$ and $89 \%$ of the total variance respectively. Box Tree Waterhole, Hancock Creek and Murtho are within the local-area and their different symbols are meant to distinguish them from the remaining plants within the local-area. Each of the trait/trait state centroids are labelled with numbers defined in the table below.

\begin{tabular}{|c|c|c|c|c|}
\hline Label & \multicolumn{2}{|c|}{ Morphological traits/trait states } & Label & Physiological traits \\
\hline 1 & Colour1 & Yellow Green & 19 & $\Delta^{13} \mathrm{C}_{\mathrm{ad}}$ \\
\hline 2 & Colour2 & Yellow Green and Green & 20 & $T N_{\text {ad }}$ \\
\hline 3 & Colour3 & Green & 21 & SLA \\
\hline 4 & Colour5 & Grey Green & & \\
\hline 5 & Colour6 & Grey Green and Yellow Green & & \\
\hline 6 & Gloss 1 & Dull & & \\
\hline 7 & Gloss2 & Intermediate & & \\
\hline 8 & Gloss 3 & Shiny & & \\
\hline 14 & Leaf Are: & & & \\
\hline 15 & $R b_{\mathrm{d}}$, Dian & eter at rough bark height & & \\
\hline
\end{tabular}


ty in this study is that there are more than 200 markers and repeatedly applying this test greatly increases the chance of type I error (rejecting the null hypothesis, when it is in fact true). To arrive at an alternative critical value that correctly has a significance level of $5 \%$, a randomization study was performed where response variables were randomised and the maximum variance ratio identified, thus ensuring the null hypothesis was in fact true. Randomisation was repeated 1000 times to produce the distribution of the variance ratio under the null hypothesis. This distribution is then used to identify the $95^{\text {th }}$ percentile, or critical value for testing each of the 200 excess repeated analyses against the observed value of the response variables - i.e. morphological and physiological traits (HANCOCK, 2002).

\section{Results}

\section{OVERALS with all AFLP DNA markers}

OVERALS of morphological and physiological traits with all 232 AFLP DNA markers produced $1^{\text {st }}$ and $2^{\text {nd }}$ dimensions accounting for 80 and $74 \%$ of variation respectively (Fig. 2a). Trait centroids occurring in the vicinity of the Green Box centroid $(-0.0445,0.191)$ reinforced their intermediacy between $E$. gracilis and E. largiflorens. Green Box leaf colour centroid yellow green $(-0.330,0.794)$ and intermediate gloss $(-0.059$, 0.746). Other trait centroids reinforcing the intermedicy of Green Box were $R b_{\mathrm{d}}(-0.239,0.578), \Delta^{13} \mathrm{C}_{\mathrm{ad}}(-0.241$, $0.204)$ and SLA $(0.066,-0.207)$. Trait centroids characterizing $E$. gracilis (centroid $-0.834,1.303$ ) were grey green and yellow green leaf colour $(-1.252,-0.488)$ and shiny gloss $(-1.733,0.037)$. Trait centroids characterizing $E$. largiflorens (centroid $0.1511,-0.685$ ) were grey green leaf colour $(0.354,-0.587)$, dull gloss $(0.350,-0.448)$, leaf area $(0.135,-0.585)$ and $T N_{\text {ad }}$ $(0.294,-0.357)$.

There were several component loadings $\left(l_{c}\right)$ for traits and AFLP markers greater than 0.3 therefore strong enough to separate groups. In the $1^{\text {st }}$ dimension, leaf colour and gloss contributed most with $l_{c}$ of 0.340 and 0.615 respectively. $T N_{\text {ad }}$ was not quite as strong, 0.294 , and $\Delta^{13} \mathrm{C}_{\mathrm{ad}}$, SLA, leaf area and $R b_{\mathrm{d}}$ did not contribute much with $l_{\mathrm{c}}$ of $-0.241,0.066,0.135$ and -0.239 respec-

Table 2. - AFLP markers significantly associated with traits (response variables) from both OVERALS and linear regression. * indicates $E$. gracilis $78 \%$ specific markers and ${ }^{\wedge}$ indicates $78 \%$ specific markers for $E$. largiflorens. For variables: $\delta^{15} \mathrm{~N}_{\mathrm{ad}}, T N_{\mathrm{ad}}, R b_{\mathrm{d}}$ and leaf colour; $n=78: 17+33+11+9+8 \mathrm{E}$. gracilis, E. largiflorens and Green Box, Hncrk progeny and Murtho progeny respectively. For $\Delta^{13} \mathrm{C}_{j} ; n=43: 6+15+5+9+8 E$. gracilis, $E$. largiflorens and Green Box, Hncrk progeny and Murtho progeny respectively. Italics indicate markers identified by OVERALS and linear regression but not by MANOVA.

\begin{tabular}{|c|c|c|c|c|}
\hline $\begin{array}{l}\text { Response } \\
\text { variable }\end{array}$ & $\begin{array}{l}\text { Critical } \\
\text { value }\end{array}$ & $\begin{array}{l}\text { Numbcr of } \\
\text { significant } \\
\text { markers } \\
(P<0.05)\end{array}$ & $\begin{array}{l}\text { Markers } \\
\text { identified }\end{array}$ & $\begin{array}{l}\text { Markers identificd with } \\
\text { MANOVA }(P)\end{array}$ \\
\hline$\delta^{15} \lambda_{\mathrm{ad}}$ & 15.8 & 2 & $\mathrm{~B} 58, \mathrm{~B} 121$ & $\begin{array}{l}\mathrm{B} 42(0.003), \mathrm{B} 58(0.001) \\
\mathrm{B} 71(0.003), \mathrm{B} 109(0.004) \\
\mathrm{L} 121(0.006), \mathrm{B} 134(0.000) \\
\mathrm{I} 184(0.003), 13196(0.005) \\
13208(0.002), 13215(0.005)\end{array}$ \\
\hline$\Delta^{13} \mathrm{C}_{\mathrm{ad}}$ & 15.5 & 0 & & \\
\hline$T N_{\text {ad }}$ & 14.6 & 2 & $B 95, \operatorname{B} 137^{*}$ & $B 95(0.000), \mathrm{B} 137^{*}(0.001)$ \\
\hline SLA & 16.0 & 0 & & \\
\hline$\Delta^{\prime 3} C_{j}$ & 16.6 & 1 & B224 & $\begin{array}{l}\mathrm{B} 202 \times(0.000), \mathrm{B} 205(0.000) \\
13224(0.000)\end{array}$ \\
\hline$R b_{d}$ & 14.9 & 10 & $\begin{array}{l}\mathrm{B33} * \mathrm{~B} 78 \\
\mathrm{~B} 85, \mathrm{~B} 137^{*} \\
13143^{*}, 13144 \\
\mathrm{~B} 161^{*}, \mathrm{~B} 162 \\
\mathrm{~B} 202^{\wedge}, \mathrm{B} 204^{\wedge}\end{array}$ & $\begin{array}{l}\mathrm{B} 30(0.020), \mathrm{B} 33^{*}(0.024), \\
\mathrm{B} 42(0.031), \mathrm{B} 67(0.001), \\
\mathrm{B} 73 *(0.007), \mathrm{B} 75(0.008), \\
B 78(0.052), \mathrm{B} 85(0.011), \\
\mathrm{B} 89(0.033), \mathrm{B} 128(0.003), \\
\mathrm{B} 136(0.030), \mathrm{B} 137 *(0.018) \text {, } \\
\mathrm{B} 138(0.032), \mathrm{B} 143 *(0.007) \text {, } \\
B 144(0.274), \mathrm{B} 161 *(0.025) \text {, } \\
\mathrm{B} 162 *(0.001), \mathrm{B} 182(0.002), \\
\mathrm{B} 193(0.027), \mathrm{B} 202^{\wedge}(0.037) \text {, } \\
B 204^{\prime}(0.083), \mathrm{B} 207(0.033), \\
\mathrm{B} 218(0.002)\end{array}$ \\
\hline $\begin{array}{l}\text { Colour } \\
\text { Categories }\end{array}$ & 14.8 & 8 & $\begin{array}{l}\mathrm{B} 33^{*}, \mathrm{~B} 66 \\
\mathrm{~B} 142^{\wedge}, \mathrm{B} 143^{*} \\
\mathrm{~B} 144, \mathrm{~B} 161^{*} \\
\mathrm{~B} 170, \mathrm{~B} 204^{\circ}\end{array}$ & $\begin{array}{l}B 33 *(0.803), \mathrm{B} 57(0.011), \\
B 66(0.309), \mathrm{B} 67(0.001) \\
\mathrm{B} 88(0.002), \mathrm{B} 399(0.011), \\
\mathrm{B} 92(0.007), \mathrm{B} 115(0.008), \\
{[3128(0.002), \mathrm{B} 142 \times(0.003),} \\
B 143 *(0.622), B 144(0.285), \\
B 161(0.059), \mathrm{B} 170(0.013), \\
\mathrm{B} 182(0.001), \mathrm{B} 194(0.005), \\
B 204(0.128)\end{array}$ \\
\hline
\end{tabular}


Table 3. - Quantifications of physiological and morphological traits associated with the presence and absence of AFLP markers identified from linear regression. Plants from local-area and outside-local area populations were included. The frequency of marker present in each of the plant groups is also shown. [n]. * indicates E. gracilis $78 \%$ specific markers and ${ }^{\wedge}$ indicates $78 \%$ specific markers for $E$. largiflorens plants identified from local area markers.

\begin{tabular}{|c|c|c|c|c|c|c|c|c|}
\hline \multirow[t]{2}{*}{ Trail } & \multirow{2}{*}{$\begin{array}{l}\text { Marke } \\
r\end{array}$} & \multicolumn{2}{|c|}{ Trait quantification ( I I SEM) } & \multicolumn{5}{|c|}{ F requency of marker presence } \\
\hline & & Absence & Presence & $\frac{5}{5}$ & 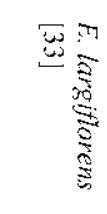 & 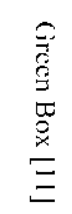 & 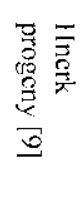 & 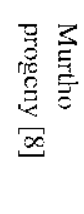 \\
\hline \multirow{5}{*}{$\begin{array}{l}\delta^{15} N_{a d} \\
(\% a) \\
T N_{a d} \\
\left(m g g^{-1}\right) \\
\Delta^{13} C_{j} \\
(\% a)\end{array}$} & B58 & $4.241(0.2904)$ & $2.067(0.3992)$ & 0.78 & 0.24 & 0.18 & 0.22 & 0.25 \\
\hline & B 121 & $1.440(0.5642)$ & $3.937(0.2639)$ & 0.44 & 0.94 & 1.00 & 0.78 & 0.88 \\
\hline & B95 & $14.00(0.5083)$ & $11.68(0.3287)$ & 0.67 & 0.73 & 0.82 & 0.56 & 0.75 \\
\hline & B $137^{*}$ & $13.48(0.3654)$ & $11.06(0.3947)$ & 1.00 & 0.39 & 0.46 & 0.00 & 0.13 \\
\hline & B224 & $17.94(0.4164)$ & $15.47(0.2] 42)$ & 0.67 & 0.85 & 0.82 & 100 & 0.88 \\
\hline \multirow{10}{*}{$\begin{array}{l}R b_{d} \\
(\mathrm{~cm})\end{array}$} & B33* & $2.795(1.1730)$ & $11.145(1.2827)$ & 0.72 & 0.12 & 0.18 & 0.11 & 0.38 \\
\hline & B85 & $6.987(1.1983)$ & $2.121(1.2315)$ & 0.17 & 0.73 & 0.36 & 0.11 & 0.25 \\
\hline & $\mathrm{B} 78$ & $3.0771(1.1730)$ & $11.145(1.2827)$ & 0.39 & 0.06 & 0.55 & 0.22 & 0.13 \\
\hline & $\mathrm{B} 137^{*}$ & $2.425(1.2068)$ & $7.768(1.2218)$ & 1.00 & 0.39 & 0.46 & 0.00 & 0.13 \\
\hline & B $143^{*}$ & $2.221(1.1842)$ & $9.670(1.2147)$ & 0.94 & 0.18 & 0.55 & 0.00 & 0.63 \\
\hline & B 144 & $8.855(1.2688)$ & $2.832(1.1872)$ & 0.28 & 0.85 & 0.46 & 1.00 & 0.63 \\
\hline & B $3161^{*}$ & $2.347(1.1748)$ & $10.740(1.2286)$ & 0.83 & 0.03 & 0.55 & 0.56 & 0.38 \\
\hline & B 162 & $3.219(1,1672)$ & $12,794(1,3763)$ & 0.39 & 0.06 & 0.09 & 0.00 & 0.63 \\
\hline & $\mathrm{B} 202^{\mathrm{A}}$ & $7.941(1.2348)$ & $2.578(1.2012)$ & 0.11 & 0.73 & 0.55 & 0.67 & 0.88 \\
\hline & $\mathrm{B} 204^{\wedge}$ & $10.475(1.2619)$ & $2.578(1.2012)$ & 0.06 & 0.91 & 0.82 & 0.67 & 0.88 \\
\hline \multirow{8}{*}{$\begin{array}{l}\text { Leaf } \\
\text { coluur }\end{array}$} & B33* & $3.750(0.2401)$ & $2.000(0.3746)$ & 0.72 & 0.12 & 0.18 & 0.11 & 0.38 \\
\hline & B66 & $3.955(0.2704)$ & $2.343(0.3032)$ & 0.72 & 0.21 & 0.73 & 0.33 & 0.50 \\
\hline & $\mathrm{B} \mid 42^{\prime \prime}$ & $2.125(0.3065)$ & $4.000(0.2529)$ & 0.28 & 0.88 & 0.36 & 0.44 & 0.63 \\
\hline & B $143^{*}$ & $4.067(0.2560)$ & $2.147(0.2945)$ & 0.94 & 0.18 & 0.55 & 0.00 & 0.63 \\
\hline & B) 44 & $2.111(0.3441)$ & $3.827(0.2479)$ & 0.28 & 0.85 & 0.46 & 1.00 & 0.63 \\
\hline & B] $61^{*}$ & $4.061(0.2368)$ & $1.900(0.3026)$ & 0.83 & 0.03 & 0.55 & 0.56 & 0.38 \\
\hline & $\mathrm{B} 170$ & $3.615(0.2221)$ & $1.500(0.4786)$ & 0.33 & 0.00 & 0.55 & 0.22 & 0.00 \\
\hline & $\mathrm{B} 204^{\wedge}$ & $1.885(0.3369)$ & $3.906(0.2359)$ & 0.06 & 0.91 & 0.82 & 0.67 & 0.88 \\
\hline
\end{tabular}

tively. Of AFLP markers, 70 out of 232 had $l_{c}$ greater than 0.3 , thirty of these could be used to predict leaf colour and ten could be used to predict leaf gloss, as their $l_{c}$ occurred with similar magnitudes and in the same direction.

Analysis with MANOVA revealed 8 out of the 9 AFLP primer combinations significantly correlated with traits, reinforcing that they were a good choice. Significance values were: 0.001 and 0.033 for $E c o A C T / M s e C A G$ and EcoACT/MseCCA respectively, 0.000 for each of the PstAG primer combinations then, 0.000, 0.003 and 0.031 for each of the EcoATG primer combinations respec tively.

\section{OVERALS with 78\% specific AFLP DNA markers}

OVERALS of morphological and physiological traits with 11 AFLP DNA markers that were $78 \%$ specific for either $E$. gracilis or $E$. largiflorens produced $1^{\text {st }}$ and $2^{\text {nd }}$ dimensions of 95 and $89 \%$ suggesting variance in traits (response variables) was adequately predicted (Fig. $2 b$ ). There was clear separation of plants into groups with Green Box intermediate. MANOVA confirmed that all 11 AFLP markers significantly correlated with traits in the 1st dimension (Wilks's lambda, $P=0.000$ ) and all had $l_{\mathrm{c}}$ greater than 0.3 indicating they adequately predicted variation in traits. Markers, B101 and B137 contributed most with $l_{c}$ of 0.658 and -0.772 respectively. Leaf area and colour in the $1^{\text {st }}$ dimension with $l_{c}$ of 0.629 and 0.641 respectively, loaded similarly to B101, indicating its presence (an E. largiflorens $78 \%$ specific marker) can predict variation in leaf area and colour. Conversely, variation in $R b_{\mathrm{d}}$ with a negative $l_{\mathrm{c}}$ of -0.692 , can be predicted by presence of B137, also with a negative $l_{\mathrm{c}}$ of -0.772 . Physiological traits did not contribute greatly with the exception of $T N_{\text {ad }}$ (0.395). Markers behaving similarly for predictive purposes were B12 (0.426) and B142 (0.437).

\section{Simple Linear Regression and Comparison with MANOVA of OVERALS component loadings}

Simple linear regression identified 17 AFLP DNA markers shown in Table 2. There was agreement between linear regression and MANOVA of OVERALS $l_{\mathrm{c}}$ for markers B58 and B121 significantly associated with $\delta^{15} \mathrm{~N}_{\text {ad }}$ (Table 2). The presence of B58 is associated with low $\delta^{15} \mathrm{~N}_{\mathrm{ad}}$, indicative of $E$. gracilis while its absence is associated with higher $\delta^{15} \mathrm{~N}_{\mathrm{ad}}$, indicative of $E$. largiflorens (Table 3). The reverse situation applied to B121, 
with its presence associated with high $\delta^{15} \mathrm{~N}_{\mathrm{ad}}$, indicative of $E$. largiflorens. Both linear regression and MANOVA of OVERALS $l_{c}$ identified two markers associating with $T N_{\text {ad }}$ : B95 and B137 (Table 2). The presence of both markers is indicative of lower concentrations of nitrogen (Table 3). Marker B224 associated with $\Delta^{13} \mathrm{C}_{\mathrm{j}}$ according to linear regression and MANOVA of OVERALS $l_{\mathrm{c}}$. There were 7 markers identified from linear regression and MANOVA of OVERALS $l_{\mathrm{c}}$ for $R b_{\mathrm{d}}$ (Table 2) and their quantifications with either presence or absence are displayed in Table 3. Linear regression identified 8 AFLP markers significantly associated with leaf colour and two of these were also identified by MANOVA of OVERALS $l_{\mathrm{c}}$ (Table 2). Their corresponding quantifications are shown in Table 3.

\section{Markers for selecting Green Box}

Of the 13 AFLP markers significant for both linear regression and MANOVA of OVERALS $l_{c}$, five had high frequencies (>0.82) in Green Box: B95, B204, B224 and B121 (Table 3). The presence of B95 is associated with lower $T N_{\text {ad }}$ indicative of Green Box and $E$. largiflorens as $E$. gracilis had higher $T N_{\text {ad }}$. The presence of B204 was associated with both $R b_{\mathrm{d}}$ and the grey green colour category, occurring in $91 \%$ of $E$. largiflorens, $82 \%$ of Green Box and only $6 \%$ of E. gracilis (Table 3). The presence of B224 was associated with low $\Delta^{13} \mathrm{C}_{\mathrm{j}}$ having highest frequency in $E$. largiflorens (85\%), lower frequency in Green Box (82\%) and lowest frequency in E. gracilis $(67 \%)$. Lastly, the presence of B121 is associated with higher $\delta^{15} \mathrm{~N}_{\text {ad }}$ indicative of Green Box and E. largiflorens (100 and $94 \%$ ) whereas E. gracilis displayed lower $\delta^{15} \mathrm{~N}_{\text {ad }}(44 \%)$.

\section{Discussion}

In this study, none of the AFLP DNA markers were $100 \%$ diagnostic for either species. Instead, analyses were conducted using all AFLP markers and markers that were at least $78 \%$ specific for $E$. largiflorens $(6$ markers) and $E$. gracilis (5 markers). Justification for using DNA markers that were not diagnostic is provided by GoODMAN et al. (1999) who stated, "Generally, genetic markers should never be treated as absolutely diagnostic because it is impossible to determine the effects of genetic heterogeneity or ancient introgression between sympatric species.

Of the $1178 \%$ specific DNA markers, one occurred beyond the local-area in 8 out of 10 Port Lincoln $E$. gracilis (B143) and another one in 9 out of 10 Wilcannia E. largiflorens (B204). Both were also present in the majority of Green Box therefore supporting their assignment as putative hybrids. This study recommends screening for more AFLP markers with high specificity for $E$. gracilis and $E$. largiflorens with the ultimate goal of encompassing natural variation extending from localarea hybrid zones to allopatric populations. Working outwards from a hybrid zone fulfils the requirement of no past introgression between putative parental species within the hybrid zone, as their specificity will have been tested against allopatric populations (TRIEST et al., 2000).
The alternative approach of linear regression was effective at singling out 17 AFLP DNA markers significantly associated with physiological and morphological traits. The remaining 215 paled into comparison indicated by much lower critical values. Linear regression has been applied elsewhere to identify markers for prediction of response variables (traits). Twelve AFLP DNA markers were associated with shoot $\mathrm{Na}^{+}, \delta^{13} \mathrm{C}$ and siteof-origin of ecogeographic data measured on 39 genotypes of wild barley (Hordeum spontaneum) (PAKNIYAT et al., 1997).

The frequency of AFLP markers was highest in either $E$. gracilis or $E$. largiflorens with Green Box displaying mostly varying frequencies. There were four markers high in frequency in Green Box and E. largiflorens and traits significantly associated with these markers were $T N_{\text {ad }}$ (B95), $\delta^{15} \mathrm{~N}_{\text {ad }}$ (B121), $R b_{\mathrm{d}}$ and leaf colour (B204) and $\Delta^{13} C_{j}$ (B224). These markers occurred with much lower frequencies in $E$. gracilis and, therefore, can be utilized to select for Green Box attributes over $E$. gracilis attributes. However, because these 4 markers occurred with similar frequencies in Green Box and $E$. largiflorens, they cannot be utilized to select for Green Box attributes over E. largiflorens attributes. To overcome this limitation, similar presence/absence of additional markers is necessary to align Green Box with $E$. gracilis. One such marker is B66 occurring with high frequencies in $E$. gracilis and Green Box and low frequency in $E$. largiflorens (Table 3). In addition the absence of markers B85 and B142 in both Green Box and $E$. gracilis distinguishes them from $E$. largiflorens. Therefore, the segregation of 7 markers can be utilized to select for Green Box. It is important to qualify that there would be other attributes of Green Box not identified in this study. More salt tolerance traits could be foliar concentrations of $\mathrm{Cl}^{-}$and ratio of sub-stomatal to ambient $\mathrm{CO}_{2}$ concentration.

It is interesting that the physiological traits identified for Green Box correspond to reduced growth potential (LAMBers et al., 2008; PoORTER and Evans, 1998). An exception was that SLA was not identified as significantly associating with Green Box or AFLP markers. The reason why is because it behaved in an intermediate manner, whereas the 7 markers identified above correspond to extremes of traits aligning Green Box with either E. largiflorens or E. gracilis. The presence of B95, B204, B224 and B121 were associated with lower $T N_{\text {ad }}$ smaller $R b_{\mathrm{d}}$, the grey green colour category, lower $\Delta^{13} \mathrm{C}_{\mathrm{j}}$ and higher $\delta^{15} \mathrm{~N}_{\text {ad }}$ in Green Box and $E$. largiflorens. Whereas, the presence of B66 and B142 was associated with low frequencies of the grey green colour category, and the presence of B85 was associated with low frequency of smaller $R b_{\mathrm{d}}$ in Green Box and E. gracilis (Table 3).

In conclusion, we have found molecular markers that correlate with physiological and morphological traits measured in E. largiflorens, Green Box and E. gracilis. The majority of these traits correspond to reduced growth potential. Green Box were hypothesized by ZUBRINICH (1996) to grow at slower growth rates because E. largiflorens had significantly higher total plant and shoot biomass. Morphological comparisons between 
$E$. gracilis, Green Box and E. largiflorens under saline conditions, indicated $E$. gracilis was slower growing at the seedling stage and maybe Green Box have inherited this quality. The seven AFLP markers identified can be used to select Green Box increasing the efficiency of revegetation strategies by selecting for favourable seedlings and thus limiting the number of seedlings that are throw backs to E. gracilis and E. largiflorens.

\section{Acknowledgements}

Flinders University of South Australia, Bookmark Biosphere Trust, now known as Riverland Biosphere Reserve (http://www.environment.gov.au/parks/ biosphere/riverland/index.html) and RITE (Research Institute of Innovative Technology for the Earth) Japan (http://www.rite.or.jp/index_e.html). This paper is dedicated to the memory of JACK V. SEEKAMP who spent a lifetime studying and working to protect the Murray River. He constructed a splendidly detailed pictorial and written record of the river extending back to the middle of the last century. Thank you to Judy Pfennig for field assistance.

\section{References}

BLAKE, T. J. (1981): Salt Tolerance of Eucalypt Species Grown in Saline Solution Culture. Australian Forest Research 11: 179-183.

BROOKER, M. I. H. (2000): A new classification of the genus Eucalyptus L'Her. (Myrtaceae). Australian Systematic Botany 13: 79-148.

Byrne, M., M. I. MarquezGarcia, T. Uren, D. S. Smith and G. F. Moran (1996): Conservation and genetic diversity of microsatellite loci in the genus Eucalyptus. Australian Journal of Botany 44: 331-341.

Byrne, M., G. F. Moran and W. N. TibBits (1993): Restriction Map and Maternal Inheritance of Chloroplast DNA in Eucalyptus-Nitens. Journal of Heredity 84: 218-220.

Chen, D. M., F. J. KeIPer and L. F. De FilipPIS (1998): Physiological changes accompanying the induction of salt tolerance in Eucalyptus microcorys shoots in tissue culture. Journal of Plant Physiology 152: 555-563.

Connolly, B. (1997): Traditional Fishery Knowledge and Practice for Sustainable Marine Resource Management in Northwestern Europe: A Comparative Study in Ireland and the Netherlands, Final Report., pp. Leiden Ethnosystems and Development Programme (LEAD), Insitute of Cultural and Social Studies, Leiden Universiteif, The Netherlands. In collaboration with Department of Zoology, University College, Galway, Ireland.

Dawson, T. E. and P. D. Brooks (2001): Fundamentals of stable isotope chemistry and measurement., pp. 1-18 in Stable Isotope Techniques in the Study of Biological Processes and Functioning of Ecosystems. Kluwer Academic Publishers, Dordrecht, The Netherlands.

Doyle, J. J. (1991): DNA protocols for plants., pp. 283-293 in Molecular Techniques in Taxonomy, edited by G. M. HewitT. Springer-Verlag, Berlin.

DoyLe, J. J. and J. L. Doyle (1990): Isolation of plant DNA from fresh tissue. Focus 12: 13-15.

Eamus, D., B. Myers, G. Duff and R. Williams (1999): A cost-benefit analysis of leaves of eight Australian savanna tree species of differing leaf life-span. Photosynthetica 36: 575-586.
FARQuhar, G. D., J. R. Ehleringer and K. T. Hubick (1989): Carbon Isotope Discrimination and Photosynthesis. Annual Review of Plant Physiology and Plant Molecular Biology 40: 503-537.

Gaiotto, F. A., M. BramucCi and D. Grattapaglia (1997): Estimation of outcrossing rate in a breeding population of Eucalyptus urophylla with dominant RAPD and AFLP markers. Theoretical and Applied Genetics 95: 842-849.

GaRson, D. G. (2002): http://www2.chass.ncsu.edu/garson/ pa765/canonic.htm, pp., edited by C. o. H. a. S. S. Professor of Public Administration, Box 8102, 2061911 Building, North Carolina State University, Raleigh, North Carolina, 27695.

Goodman, S. J., N. H. Barton, G. Swanson, K. Abernethy and J. M. PEMBERTON (1999): Introgression through rare hybridization: A genetic study of a hybrid zone between red and sika deer (genus Cervus) in Argyll, Scotland. Genetics 152: 355-371.

HANCOCK, T. (2002) :Relating response variables to AFLP Banding Data., pp. Biometrics SA, The University of Adelaide, Adelaide, Australia.

Handley, L. L., D. Robinson, B. P. Forster, R. P. Ellis and C. M. Scrimgeour et al. (1997): Shoot delta N-15 correlates with genotype and salt stress in barley. Planta 201: 100-102.

HöGBERG, P. (1997): Tansley review No 95 - N-15 natural abundance in soil-plant systems. New Phytologist 137: 179-203.

JARWAL, S. D., G. R. WALKER and I. D. JOLLY (1996): General Site Description., pp. 5-20 in Salt and water movement in the Chowilla floodplain., edited by G. R. WALKER, I. D. JOLLY and S. D. JARWAL. CSIRO Division of Water Resources, Canberra.

Jessop, J. P., H. R. ToELKEN and J. M. BlaCk (1986): Flora of South Australia. South Australian Government Printing Division, Adelaide.

KInGSFORD, R. T. (2000): Ecological impacts of dams, water diversions and river management on floodplain wetlands in Australia. Austral Ecology 25: 109-127.

Koerber, G. R., J.V. Seekamp, P. A. Anderson, M. A. Whalen and S. D. Tyerman (2012): A putative hybrid of Eucalyptus largiflorens growing on salt- and droughtaffected floodplains has reduced specific leaf area and leaf nitrogen. Australian Journal of Botany 60(4): 358-367.

Lambers, H., F. Stuart Chapin III and T. L. Pons (2008): Plant Physiological Ecology. Springer, New York.

Lloyd, J., J. P. Syvertsen, P. E. Kriedemann and G. D. FARQUHAR (1992): Low Conductances for $\mathrm{CO}_{2}$ DifFUSION from Stomata to the Sites of Carboxylation in Leaves of Woody Species. Plant Cell and Environment 15: 873-899.

Margules and Partners, P. and J. SMith and F. A. L. VicTORIAN DEPARTMENT OF CONSERVATION (1990): River Murray riparian vegetation study., pp. 187. prepared for the Murray-Darling Basin Commission, Canberra, Australia.

Marques, C. M., J. A. Araujo, J. G. Ferreira, R. WhetTEN and D. M. O'MALLEY et al. (1998): AFLP genetic maps of Eucalyptus globulus and E. tereticornis. Theoretical and Applied Genetics 96: 727-737.

McKinnon, G. E., R. E. Vaillancourt, D. A. Steane and B. M. PotTs (2008): An AFLP marker approach to lowerlevel systematics in Eucalyptus (Myrtaceae). American Journal of Botany 95: 368-380. 
Morabito, D., D. Mills, D. Prat and P. Dizengremel (1994): Response of Clones of Eucalyptus-Microtheca to $\mathrm{NaCl}$ in-vitro. Tree Physiology 14: 201-210.

MYeRs, B. A. (1995): The Influence of the Lignotuber on Hydraulic Conductance and Leaf Cinductance in Eucalyptus-Behriana Seedlings. Australian Journal of Plant Physiology 22: 857-863.

NEC (1988): Chowilla Salinity Mitigation Scheme - Draft Environmental Impact Statement., pp., Report prepared by Natural Environment Consultancy for the Engineering and Water Supply Department of South Australia.

NisnemeTs, U. (1999): Components of leaf dry mass per area - thickness and density - alter leaf photosynthetic capacity in reverse directions in woody plants. New Phytologist 144: 35-47.

O'MALley, C. and F. SHeldon (1990): Chowilla Floodplain Biological Study., pp. Nature Conservation Society of South Australia, Adelaide, South Australia.

Overton, I. and T. Doody (2010): Ecosystem response modelling in the Chowilla Floodplain, Lindsay and Wallpolla Islands icon site., pp. 357-372 in Ecosystem Response Modelling in the Murray Darling Basin, edited by N. a. O. SAINTILAN, I. CSIRO Publishing, Collingwood, Victoria.

Pakniyat, H., W. Powell, E. Baird, L. L. Handley and D. RoBINSON et al. (1997): AFLP variation in wild barley (Hordeum spontaneum C. Koch) with reference to salt tolerance and associated ecogeography. Genome 40: 332-341.

PARKER, G. D. (1998): Identification of molecular markers linked to quantitative traits and disease resistance genes in wheat (Triticum aestivum L.), pp. The University of Adelaide, Adelaide, South Australia.

Parsons, R. F. and T. M. Zubrinich (2010): The greenleaved variant of Eucalyptus largiflorens: a story involving hybridization and observant local people. Cunninghamia 11: 413-416.

Poorter, H. and J. R. Evans (1998) Photosynthetic nitrogen-use efficiency of species that differ inherently in specific leaf area. Oecologia 116: 26-37.

Poorter, H. and E. GARNIER (1999): Ecological significance of inherent variation in relative growth rate., pp. 81-120 in Handbook of Functional Plant Ecology, edited by F. I. Pugnaire, F. Valladares and M. Dekker, New York.

Powell, W., W. T. B. Thomas, E. Baird, P. Lawrence and A. Booth et al. (1997): Analysis of quantitative traits in barley by the use of amplified fragment length polymorphisms. Heredity 79: 48-59.

Quarrie, S. A., D. A. Laurie, J. H. Zhu, C. Lebreton and A. SEMIKHODSKII et al. (1997); QTL analysis to study the association between leaf size and abscisic acid accumulation in droughted rice leaves and comparisons across cereals. Plant Molecular Biology 35: 155-165.
Reich, P. B., M. B. Walters, M. G. TJoelker, D. VanDERKLEIN and C. BuschenA (1998): Photosynthesis and respiration rates depend on leaf and root morphology and nitrogen concentration in nine boreal tree species differing in relative growth rate. Functional Ecology 12: 395-405.

Robinson, D., L. L. Handley, C. M. Scrimgeour, D. C. Gordon and B. P. Forster et al. (2000): Using stable isotope natural abundances (delta N-15 and delta C-13) to integrate the stress responses of wild barley (Hordeum spontaneum C. Koch.) genotypes. Journal of Experimental Botany 51: 41-50.

Schieving, F. and H. Poorter (1999): Carbon gain in a multispecies canopy: the role of specific leaf area and photosynthetic nitrogen-use efficiency in the tragedy of the commons. New Phytologist 143: 201-211.

Sharley, T. and C. HugGan (1995): Chowilla Resource Management Plan., pp. Murray-Darling Basin Commission's Chowilla Working Group, Canberra, Australia.

Skabo, S., R. E. Vaillancourt and B. M. Potts (1998): Fine-scale genetic structure of Eucalyptus globulus ssp. globulus forest revealed by RAPDs. Australian Journal of Botany 46: $583-594$.

Stevens, J. (1986): Applied multivariate statistics for the social sciences. Hillsdale, NJ: Erlbaum.

Triest, L., B. De Greef, R. De Bondt and J. VAN Slycken (2000): RAPD of controlled crosses and clones from the field suggests that hybrids are rare in the Salix albaSalix fragilis complex. Heredity 84: 555-563.

Vos, P., R. Hogers, M. Bleeker, M. Reijans and T. VANDELEE et al. (1995): AFLP - a New Technique for DNAFingerprinting. Nucleic Acids Research 23: 4407-4414.

Wang, Y., G. L. ReighaRd, D. R. LAYNe, A. G. ABBott and H. HUANG (2005): Inheritance of AFLP Markers and Their Use for Genetic Diversity Analysis in Wild and Domesticated Pawpaw [Asimina triloba (L.) Dunal]. Journal of the American Society of Horticultural Science 130: $561-568$.

Wright, I. J., P. K. Groom, B. B. Lamont, P. Poot, and L. D. PRIOR et al. (2004): Leaf trait relationships in Australian plant species. Functional plant biology 31: 551-558.

YounG, W. P., J. M. SchuPP and P. KeIM (1999): DNA methylation and AFLP marker distribution in the soybean genome. Theoretical and Applied Genetics 99: 785-792.

ZUBRINICH, T. M. (1996): An investigation of the ecophysiological, morphological and genetic characteristics of Eucalyptus largiflorens F. Muell and Eucalyptus gracilis F. Muell; in relation to soil salinity and groundwater conditions throughout the Chowilla Anabranch, pp. xi,[338] leaves.

Zubrinich, T. M., B. Loveys, S. Gallasch, J. V. Seekamp and S. D. TYERMAN (2000): Tolerance of salinized floodplain conditions in a naturally occurring Eucalyptus hybrid related to lowered plant water potential. Tree Physiology 20: 953-963. 